\title{
Encounter of lithodid crab Paralomis birsteini on the continental slope off Antarctica, sampled by ROV
}

\author{
Sven Thatje $\cdot$ Sally Hall $\cdot$ Chris Hauton . \\ Christoph Held • Paul Tyler
}

Received: 29 February 2008 / Revised: 28 April 2008 / Accepted: 2 May 2008 / Published online: 27 May 2008

(C) Springer-Verlag 2008

\begin{abstract}
A population of stone crab (Lithodidae) was encountered on the continental slope off Antarctica in the Bellingshausen Sea between 1,123 and $1,304 \mathrm{~m}$ water depths using the ROV-Isis during leg 166 of the RV James Clark Ross, in January 2007. Specimens were video recorded and one specimen was retrieved by ROV for morphological and molecular identification. Based on morphology and molecular data from the mitochondrial COI gene, this specimen identified as $P$. birsteini, Macpherson, 1988a. The significance of the molecular data and their implications for biogeography and evolution of lithodids in the Southern Ocean are briefly discussed.
\end{abstract}

Keywords Southern Ocean · Stone crab ·

Molecular phylogeny $\cdot$ Biogeography

\section{Introduction}

The shallow waters of the Antarctic continental shelf are virtually free of benthic top predators, such as shark, rays, teleost fish, and crabs (Aronson et al. 2007). The absence of such predators results from harsh physiological constraints, mainly low temperature that has prevailed in this environment for tens of millions of years. The process of Antarctic cooling was

S. Thatje $(\bowtie) \cdot$ S. Hall $\cdot$ C. Hauton $\cdot$ P. Tyler

National Oceanography Centre, Southampton,

School of Ocean and Earth Science,

University of Southampton, European Way,

Southampton SO14 3ZH, UK

e-mail: svth@noc.soton.ac.uk

C. Held

Alfred Wegener Institute for Polar and Marine Research, Marine Animal Ecology, Am Alten Hafen 26,

27568 Bremerhaven, Germany initiated by the breakup of Gondwana in the early Eocene, with a last cooling step until about 14 million years ago that resulted in conditions similar to those as seen today (see Aronson et al. 2007, and references therein). Since then, and in the absence of top predators structuring the faunal community, the Antarctic benthos of the shallow continental shelf evolved and maintained a rather ancient structure that today is not found anywhere else on Earth (Aronson et al. 2007).

The increased records of lithodid crabs in deeper waters and on seamounts surrounding the Antarctic continent in recent years raised the question of established lithodid crab populations in the Southern Ocean (López Abellan and Balguerías 1993; Klages et al. 1995; Arana and Retamal 1999; Thatje and Arntz 2004; Thatje and Lörz 2005). Although the origin and especially the timescale of lithodid radiation in the Southern Ocean remains obscure (Thatje et al. 2005), there is consensus that these largest arthropods currently inhabiting the oceans are the most likely candidates to invade the shallow waters of the Antarctic continental shelf under conditions of climate change (Meredith and King 2005; Thatje et al. 2005). Warming is likely to remove physiological barriers on lithodid crabs that currently place a limit on the invasion of shallow waters of the high Antarctic; a scenario that is especially likely for waters off the Antarctic Peninsula (Aronson et al. 2007, and references therein).

First records of lithodid crabs of the species Neolithodes capensis and Paralomis birsteini from 1,408 to 1,947 m, respectively, were made on the continental rise of Antarctica in the Bellingshausen Sea (García Raso et al. 2005). P. birsteini now appears to be widespread in the Bellingshausen Sea and so far remains the most commonly recorded Antarctic lithodid species south of $60^{\circ} \mathrm{S}$ (Arana and Retamal 1999; Thatje and Arntz 2004; Ahyong and Dawson 2006).

In the present work, we present new records of $P$. birsteini Macpherson, 1988a (=P. spectabilis Birstein and 
Vinogradov 1967, not Hansen 1908) from 1,100 to $1,400 \mathrm{~m}$ water depths in the Bellingshausen Sea, which constitute the shallowest records of lithodids on the continental slope/ rise of Antarctica. Comparative analysis of a fragment of the mitochondrial cytochrome oxidase I gene from the sampled specimen of $P$. birsteini and sequences obtained from related species are discussed from a biogeographical and evolutionary point of view.

\section{Materials and methods}

Sampling - thirteen specimens of the lithodid genus Paralomis were video-recorded on the continental slope/rise off
Antarctica in the Bellingshausen Sea between 1,123 and 1,394 m water depth using the ROV-Isis during leg 166 of the RV James Clark Ross in January 2007 (Fig. 1, dive stations 5 and 6, Tyler et al. 2007). One male specimen (Fig. 2a-d) was sampled using the ROV's manipulator arm $\left(66^{\circ} 24^{\prime} 81 \mathrm{~S} ; 71^{\circ} 30^{\prime} 79 \mathrm{~W} ; 1,394 \mathrm{~m}\right)$. The specimen was surfaced and died shortly thereafter.

Species identification-Morphological identification followed descriptions by Macpherson (1988a) in the form of the carapace and the antennal acicle, and additional comparison was made with other specimens of $P$. birsteini from the Musée National d'Histoire Naturelle (MNHN) in Paris. The specimen examined was $65 \mathrm{~mm}$ of Carapace Length (CL), measured from the orbit to the posterior carapace
Fig. 1 Biological dive stations with the ROV-Isis during leg 166 of RV James Clark Ross to the Antarctic Bellingshausen Sea in January/February 2007. Specimens of the lithodid crab Paralomis birsteini were encountered during dive Nos. 5 \& 6 (starting points: $68^{\circ} 23^{\prime} 48 \mathrm{~S}$; $71^{\circ} 32^{\prime} 95 \mathrm{~W}$ and $66^{\circ} 24^{\prime} 24 \mathrm{~S}$; $71^{\circ} 81^{\prime} 82 \mathrm{~W}$, respectively) on the continental slope/rise off the Western Antarctic Peninsula

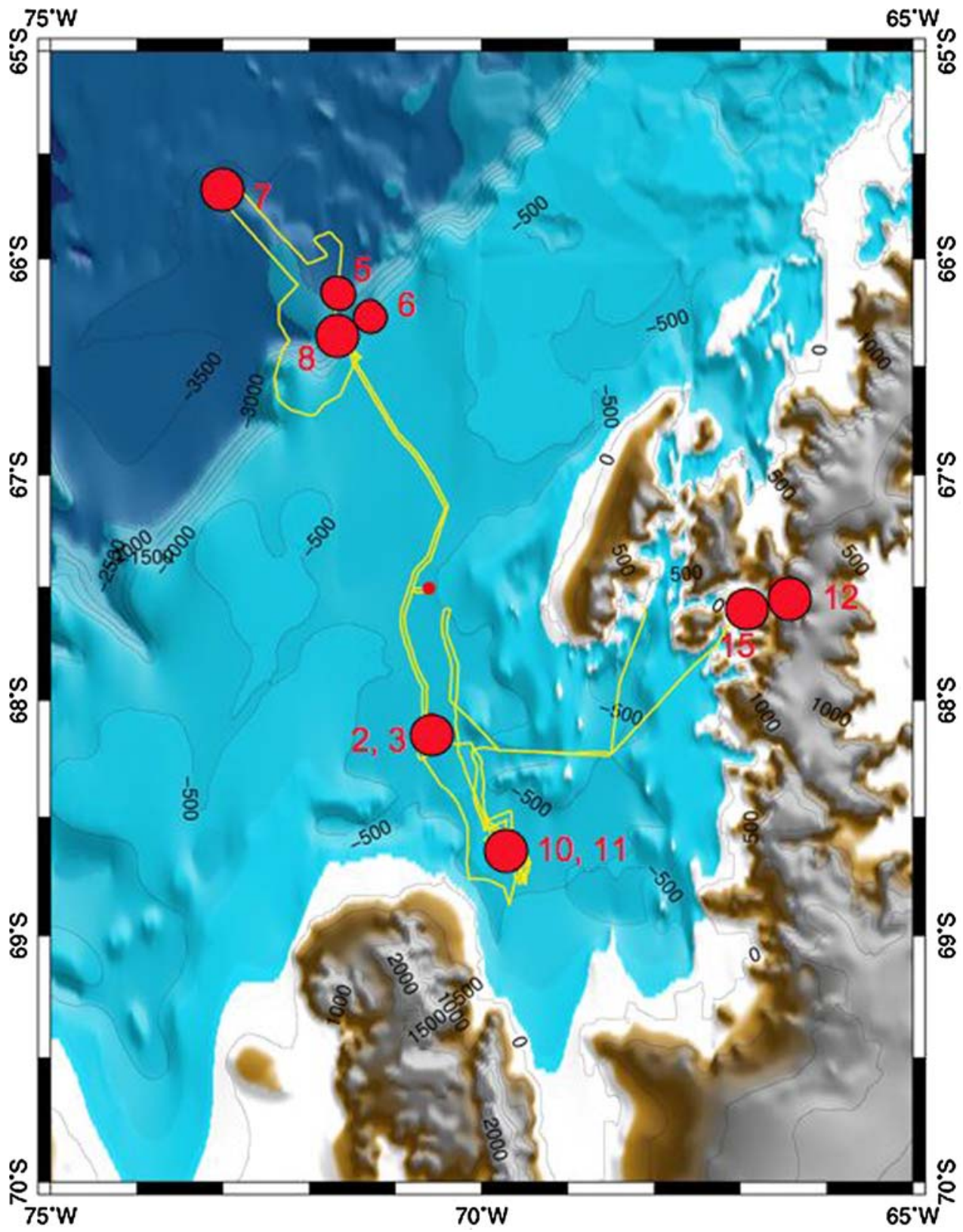


Fig. 2 Male specimen of Paralomis birsteini on the continental slope off Antarctica, Bellingshausen Sea, sampled by ROVIsis during leg JCR166 on 25 January 2007. P. birsteini in its natural habitat $(\mathbf{a}, \mathbf{b})$, sampled by ROV-Isis (c, d), specimen $\mathrm{CL}=64.9 \mathrm{~mm}$
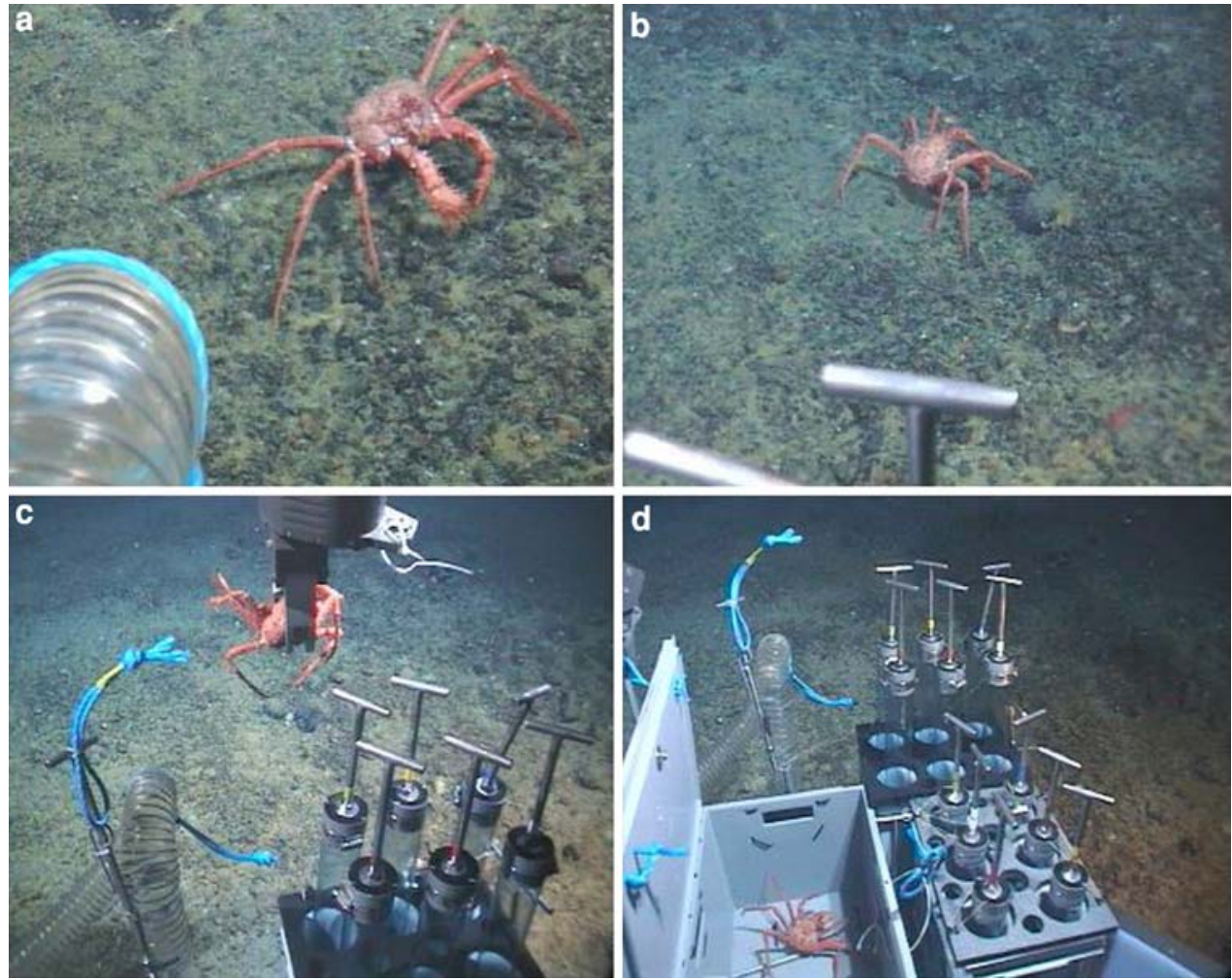

edge, and making it similar in size to the nominal $P$. birsteini (two paratypes studied: maximum $\mathrm{CL}=67.78 \mathrm{~mm}$; maximum $\mathrm{CW}=67.74 \mathrm{~mm}$ ).

DNA extraction, PCR, and sequencing-Tissue was sampled from the dactylus muscle of the retrieved sample and preserved in pre-cooled, $70 \%$ ethanol. Muscle samples from related species were also frozen very soon after death. DNA was extracted using Qiagen (Hilden, Germany) DNeasy Blood \& Tissue kits following manufacturers' protocol. Using universal primers HCO2198 and LCO1490 (Folmer 1994) and Qiagen Taq polymerase approximately
$850 \mathrm{bp}$ of the mitochondrial COI gene were amplified (Saiki et al. 1988). The amplicons were cleaned using Qiagen QIAquick purification columns and sent to Macrogen Inc (Korea) for sequencing. Sequences can be retrieved from GenBank (Table 1).

Alignment and phylogenetic analyses-DNA sequences were aligned with no gaps or ambiguity using the Clustal W program (Thompson et al. 1994). Identical sequences were omitted from the analysis. Alignments were run through Modeltest 3.7 to obtain estimates of parameters for Maximum likelihood analysis. Phylogenetic trees were inferred

Table 1 Collection data for the lithodid specimens studied

\begin{tabular}{|c|c|c|c|c|c|}
\hline Morphological ID & Lat & Long & Genbank accession & Identified by & Caught by \\
\hline Paralomis spinosissima & $53^{\circ} 36 \mathrm{~S}$ & $36^{\circ} 38^{\prime} \mathrm{W}$ & EU493258 & S. Hall & Long line off South Georgia \\
\hline Paralomis spinosissima & $53^{\circ} 36^{\prime} \mathrm{S}$ & $36^{\circ} 38^{\prime} \mathrm{W}$ & EU493259 & S. Hall & Long line off South Georgia \\
\hline Paralomis birsteini & $66^{\circ} 24^{\prime} 81 \mathrm{~S}$ & $71^{\circ} 30^{\prime} 79 \mathrm{~W}$ & EU493260 & S. Hall & JCR166 ROV-Isis \\
\hline Paralomis birsteini & $48^{\circ} 2^{\prime} \mathrm{S}$ & $71^{\circ} 18^{\prime} \mathrm{E}$ & EU493261 & S. Hall & $\begin{array}{l}\text { Palangrier Aldbaran, Kerguelen } \\
\text { St Pal. } 60 \text { 6/12/1999 }\end{array}$ \\
\hline Paralomis formosa & $53^{\circ} 36^{\prime} \mathrm{S}$ & $36^{\circ} 38^{\prime} \mathrm{W}$ & EU493262 & S. Hall & Long line off South Georgia \\
\hline Paralomis formosa & $53^{\circ} 36^{\prime} 4.42^{\prime \prime} \mathrm{S}$ & $36^{\circ} 38^{\prime} 43.86^{\prime \prime} \mathrm{W}$ & EU493265 & M. Belchier & Long line off South Georgia \\
\hline Paralomis granulosa & $54^{\circ} 47^{\prime} 59.14^{\prime \prime} \mathrm{S}$ & $65^{\circ} 15^{\prime} 0.15^{\prime \prime} \mathrm{W}$ & EU493264 & G.A. Lovrich & $\begin{array}{l}\text { Artisanal trap fisheries, } \\
\text { Beagle Channel }\end{array}$ \\
\hline Lithodes confundens & $54^{\circ} 47^{\prime} \mathrm{S}$ & $65^{\circ} 15^{\prime} \mathrm{W}$ & EU493257 & S. Hall & ICEFISH 04, st 10T1 \\
\hline Neolithodes brodiei & $14^{\circ} 44^{\prime} 48 \mathrm{~S}$ & $167^{\circ} 8^{\prime} 40 \mathrm{E}$ & EU493263 & $\begin{array}{l}\text { Original, } \\
\text { E. Macpherson; } \\
\text { Reviewed S. Hall }\end{array}$ & $\begin{array}{l}\text { BOAO Alis CP } 2312 \\
\text { Vanuatu, 15/11/2004 }\end{array}$ \\
\hline Pagurus bernhardus & Unknown & Unknown & AF483157 & Young et al. Genbank & Unknown \\
\hline
\end{tabular}


from DNA sequences using PAUP 4 beta version 10 . Outgroups were taken from both within the family Lithodidae (Neolithodes brodiei and Lithodes confundens), and from a closely related group (Pagurus bernhardus). Inclusion of either lithodid outgroup did not change the outcome. In addition, an iterative Bayesian analysis was run with Mrbayes 3.1 (Huelsenbeck and Ronquist 2001; Ronquist and Huelsenbeck 2003). The trees are presented for comparison (Fig. 3a, b).

\section{Results}

Thirteen specimens of $P$. birsteini were video recorded between about 1,123 and 1,394 m water depths on the Antarctic continental slope/rise in the Bellingshausen Sea (Figs. 1, 2). The present video footage included the record of one juvenile specimen of less than $2 \mathrm{~cm} C L$ in a gravel substratum that tried to escape the ROV's slurp gun and unfortunately was destroyed during hovering.

The genus Paralomis is well supported in the present molecular work, with species from the South Atlantic and

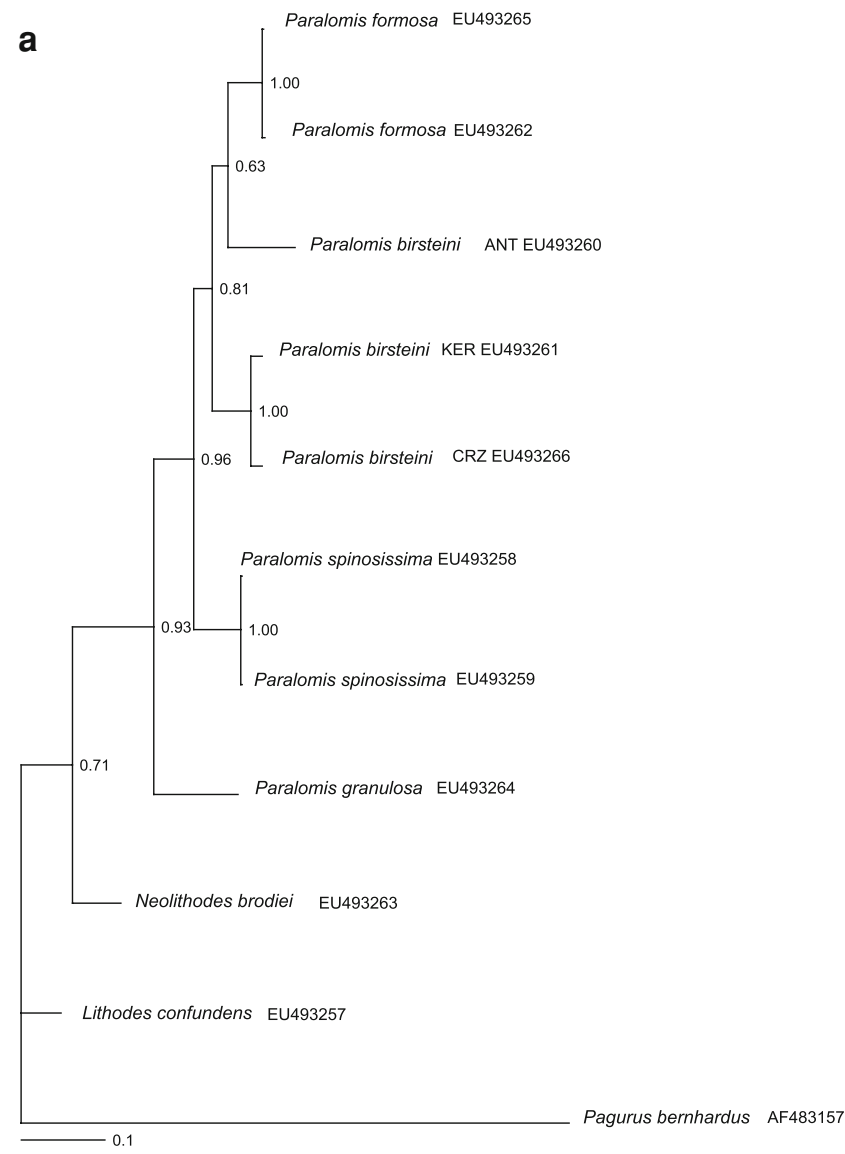

Fig. 3 a Phylogram produced using the Mrbayes program, displaying Bayesian posterior probabilities at the internal nodes. Genbank accession numbers provided. ANT Bellingshausen Sea, CRZ Crozet, KER
Indian oceans clustering very closely together. While the phylogeny doesn't resolve fully with molecular methods, the recognized morphospecies of Paralomis spinosissima and $P$. formosa are upheld (Fig. 3a, b). It may be of significance that the specimens of $P$. birsteini from the Crozet Islands appear in this analysis distinct from the specimen in question despite close morphological similarity. Comparative analysis of a fragment of the mitochondrial cytochrome oxidase I gene from the sampled specimen of $P$. birsteini and sequences obtained from related species indicates a close affinity of species of Paralomis from either side of the Scotia arc and the Bellingshausen Sea (Fig. 3a, b). Relationships within this group cannot be further resolved based on the present data.

\section{Discussion}

Paralomis birsteini is morphologically closely related to $P$. spectabilis, which so far has only been found off Iceland and eastern Greenland at depths ranging from 1,470 to 2,075 m (Macpherson 1988b) and P. formosa Henderson,

b

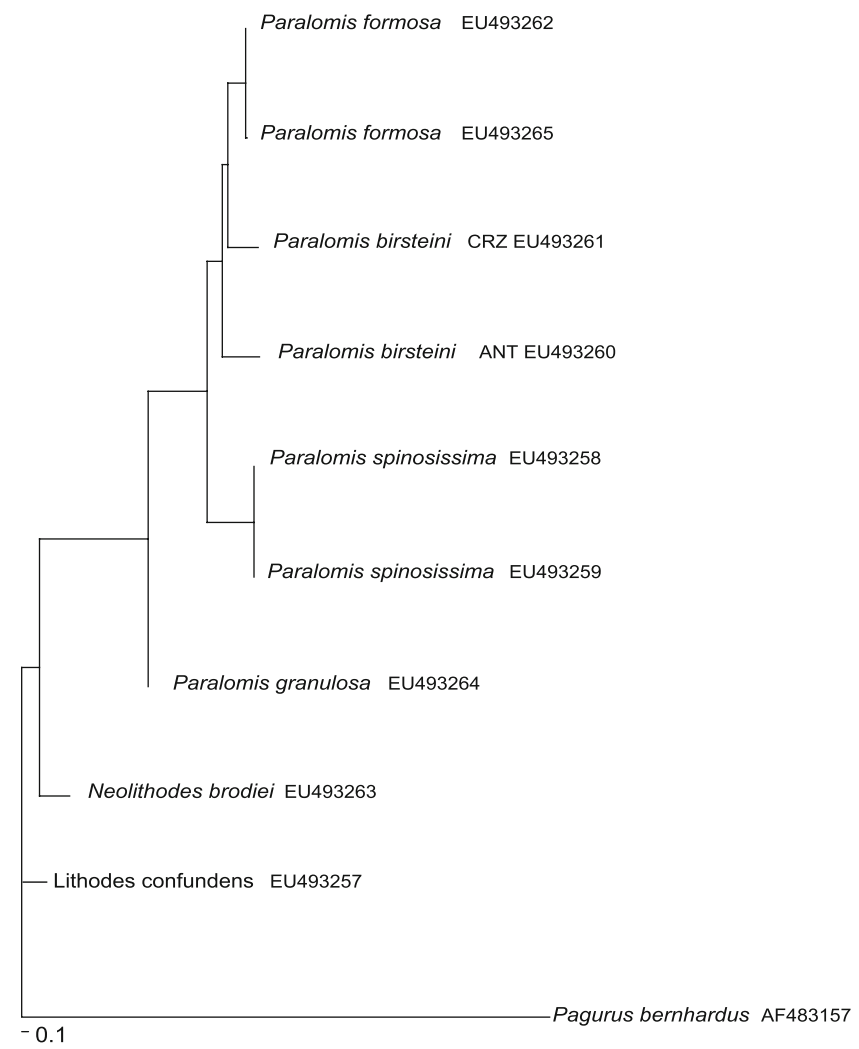

Kerguelen Plateau. b Phylogram produced using PAUP 4 beta 10 using a Maximum Likelihood Method and a GTR_G_I model of substitution. $A N T$ Bellingshausen Sea, CRZ Crozet, KER Kerguelen Plateau 
which is common in waters off the island of South Georgia in the South Atlantic, at depths ranging from around 300 to $1,700 \mathrm{~m}$ (Thatje et al. 2005). P. birsteini is distinguished from $P$. spectabilis by shorter, stouter legs and the dactylus shorter than the propodus in $P$. spectabilis; the rostrum not pedunculate in $P$. birsteini, which is pedunculate in $P$. spectabilis; and the antennal acicle having short spines on its inner surface in P. birsteini (for details see Birstein and Vinogradov 1967; Macpherson 1988a). Personal observations of southern ocean $P$. birsteini specimens (Table 1) reveal a high degree of variability in these character states, and we recognize little substantial difference between the two species.

$P$. birsteini distinguishes from $P$. formosa in having longer legs and less prominent spines than in P. formosa; $P$. formosa has a large spine in the centre of its gastric region drawn out anteriorly which makes this region very convex. This spine is present but less pronounced in P. birsteini. $P$. formosa is also distinguishable by having long slender spines variable in number on both sides of its antennal acicle, and in having its carapace and walking legs covered completely in granules (although this disappears in larger individuals; for details see Macpherson 1988b).

Because only one specimen was retrieved by ROV for morphological and molecular studies it remains unclear whether other species of Paralomis co-occur with P. birsteini in the same habitat, which is not uncommon in this genus (Thatje and Arntz 2004). So far, species from other lithodid genera, Neolithodes and Lithodes, and Paralomis have been recorded for the Bellingshausen Sea and the Scotia arc region (Thatje and Arntz 2004; García Raso et al. 2005).

This record of a juvenile specimen of $P$. birsteini may indicate a reproductively active population in the area under investigation, given that lithodid species in the Southern Ocean are assumed to possess a low potential for larval dispersal. This was frequently discussed to be due to demersally drifting, lecithotrophic larvae with limited swimming ability, as found in several species from southern high latitudes based on field and laboratory observations (Lovrich 1999; Thatje et al. 2003; Watts et al. 2006; Reid et al. 2007). Radiation in Southern Ocean lithodids is thus likely dependent on adult migration, although one may indeed discuss the potential of demersally drifting larvae in bottom currents to distribute over long distance, given that larval development in Southern Ocean lithodids is likely exceeding 4-5 months in duration (Thatje et al. 2005). The topic needs much closer future investigation.

The phylogenetic analysis of the COI gene of Paralomis species from either side of the Scotia arc indicates a close affinity of species from South Georgia ( $P$. formosa and $P$. spinosissima) with morphologically similar groups from as far away as Crozet in the Indian Ocean, and the Bellings- hausen Sea (Table 1, Fig. 3a, b). Although defined species do show constant morphological characters that aid identification of morphospecies (Macpherson 1988a, b) the molecular analysis provides an initial suggestion of an ongoing or very recent speciation process within this group in the Southern Atlantic/Indian Ocean.

Analysis of the COI gene in the Bellingshausen Sea specimen of Paralomis birsteini allows us to suggest that gene flow within this morphotype is limited over distance, possibly to the extent of a cryptic speciation. Cryptic speciation has been previously discovered in other Antarctic taxa with limited dispersal potential (Held and Wägele 2005; Raupach and Wägele 2006). Genetic differences between $P$. birsteini from three different localities presented in this work (Fig. 3a, b) could point at a species complex that consists of at least two cryptic species. This supports the necessity of comparative analyses among type locality specimens from around Antarctica and adjacent seas in order to unravel biogeography and radiation patterns of Antarctic invertebrates in general.

Relatively close phylogenetic relationships between south Atlantic and Bellingshausen species supports hypothesis of a biogeographic relationship between these two areas (Gorny 1999), and gives further insight into the potential colonization of Antarctica from lower latitudes. Given that dispersal of larvae and thus potential gene flow between populations of Southern Ocean is discussed to be very low (Thatje et al. 2003; Watts et al. 2006), the close-relatedness of species across the Scotia Arc could point at a relatively recent separation of species and possible radiation in the Southern Ocean. Evolutionary timescales and exact radiation patterns of lithodid species remain obscure (Zaklan 2002; Thatje et al. 2005) and such work is so far particularly biased by the lack of sufficient numbers of lithodid specimens from Antarctic waters available for phylogenetic and molecular studies.

Acknowledgments We are grateful to the crew of R.V. James Clark Ross and the ROV-Isis team (NOCS) for help and assistance at sea, and to Julian Dowdeswell (SPRI, Cambridge) for the organization of leg JCR166. Molecular work was made possible by a travel grant from the German Academic Exchange Service (DAAD) to S.H. and a Research Grant from The Royal Society (2006-R2) to S.T. The ROV-cruise on board RV James Clark Ross was funded by NERC (project no. NE/ D008352/1, P.I. Tyler). The authors are grateful for the valuable comments made by three anonymous reviewers. This work is a contribution to the Network of Excellence MarBEF under the sixth European Framework Programme (contract no. GOCE-CT-2003-505446).

\section{References}

Ahyong ST, Dawson EW (2006) Lithodidae from the Ross Sea, Antarctica, with descriptions of two new species (Crustacea: Decapoda: Anomura). Zootaxa 1303:45-68 
Arana PM, Retamal MA (1999) Nueva distribución de Paralomis birsteini Macpherson 1988 en aguas antárticas (Anomura, Lithodidae, Lithodinae). Invest Mar (Valparaíso) 27:101-110

Aronson RB, Thatje S, Clarke A, Peck LS, Blake DB, Wilga CD, Seibel BA (2007) Climate change and invasibility of the Antarctic benthos. Annu Rev Ecol Evol Syst 38:129-154

Birstein YA, Vinogradov LG (1967) Occurrence of Paralomis spectabilis Hansen (Crustacea, Decapoda, Anomura) in the Antarctic. Explorations of the fauna of the sea. IV (XII). Biol Res Soviet Ant Exp 3:390-398 (Israel Program for Scientific Translations)

Folmer O, Black M, Hoeh W, Lutz R, Vrijenhoek R (1994) DNA primers for amplification of mitochondrial cytochrome $C$ oxidase subunit I from metazoan invertebrates. Molec Mar Biol Biotech 3:294-299

García Raso JE, Manjón-Cabeza ME, Ramos A, Olasi I (2005) New record of Lithodidae (Crustacea, Decapoda, Anomura) from the Antarctic (Bellingshausen Sea). Polar Biol 28:642-646

Gorny M (1999) On the biogeography and ecology of the Southern Ocean decapod fauna. Scient Mar 63:367-382

Hansen HJ (1908) Crustacea Malacostraca. I. Dan Ingolf Exp 3:1-120

Held C, Wägele JW (2005) Cryptic speciation in the giant Antarctic isopod Glyptonotus antarcticus (Isopoda: Valvifera: Chaetiliidae). Scient Mar 69:175-181

Huelsenbeck JP, Ronquist F (2001) MRBAYES: Bayesian inference of phylogeny. Bioinformatics 17:754-755

Klages M, Gutt J, Starmans A, Bruns T (1995) Stone crabs close to the Antarctic continent: Lithodes murrayi Henderson, 1888 (Crustacea; Decapoda; Anomura) off Peter I Island (68 $\left.51^{\prime} \mathrm{S}, 91^{\circ} 51^{\prime} \mathrm{W}\right)$. Polar Biol 15:73-75

López Abellan LJ, Balguerías E (1993) On the presence of Paralomis spinosissima and Paralomis formosa in catches taken during the Spanish Survey ANTARTIDA 8611. CCAMLR Sci 1:165-173

Lovrich GA (1999) Seasonality of larvae of Brachyura and Anomura (Crustacea, Decapoda) in the Beagle Channel, Argentina. Scient Mar 63(Suppl 1):347-354

Macpherson E (1988a) Three new species of Paralomis (Crustacea, Decapoda, Anomura, Lithodidae) from the Pacific and Antarctic oceans. Zool Scripta 17:69-75

Macpherson E (1988b) Revision of the family Lithodidae Samouelle, 1819 (Crustacea, Decapoda, Anomura) in the Atlantic Ocean. Monogr Zool Mar 2:9-153

Meredith MP, King JC (2005) Rapid climate change in the ocean west of the Antarctic Peninsula during the second half of the 20th century. Geophys Res Lett 32:L19604
Raupach MJ, Wägele JW (2006) Distinguishing cryptic species in Antarctic Asellota (Crustacea: Isopoda) - a preliminary study of mitochondrial DNA in Acanthaspidia drygalskii. Antarct Sci 18:191198

Reid W, Watts J, Clarke S, Belchier M, Thatje S (2007) Egg development, hatching rhythm and moult patterns in reared Paralomis spinosissima (Decapoda: Anomura: Paguroidea: Lithodidae) from South Georgia waters (Southern Ocean). Polar Biol 30:1213-1218

Ronquist F, Huelsenbeck JP (2003) MRBAYES 3: Bayesian phylogenetic inference under mixed models. Bioinformatics 19:15721574

Saiki R, Gelfand DH, Stoffel S, Scharf SJ, Higuchi R, Horn GT, Mullis KB, Erlich HA (1988) Primer directed enzymatic amplification of DNA with a thermostable DNA polymerase. Science 239:487491

Thatje S, Calcagno JA, Lovrich GA, Sartoris FJ, Anger K (2003) Extended hatching periods in the Subantarctic lithodid crabs Lithodes santolla and Paralomis granulosa (Crustacea: Decapoda). Helgol Mar Res 57:110-113

Thatje S, Arntz WE (2004) Antarctic reptant decapods: more than a myth? Polar Biol 27:195-201

Thatje S, Lörz AN (2005) First record of lithodid crabs from Antarctic waters off the Balleny Islands. Polar Biol 28:334-337

Thatje S, Anger K, Calcagno JA, Lovrich GA, Pörtner HO, Arntz WE (2005) Challenging the cold: crabs reconquer the Antarctic. Ecology 86:619-625

Thompson JD, Higgins DG, Gibson TJ (1994) Clustal W. Nucleic Acids Res 22:4673-4680

Tyler PA and participants (2007) NERC Cruise report. James Clark Ross Cruise No. 166 (in association with JCR cruise no. 157). pp 18 (unpublished report)

Watts J, Thatje S, Clarke S, Belchier M (2006) A description of larval and early juvenile development in Paralomis spinosissima (Decapoda: Anomura: Paguroidea: Lithodidae) from South Georgia waters (Southern Ocean). Polar Biol 29:1028-1038

Zaklan SD (2002) Review of the family Lithodidae (Crustacea: Anomura: Paguroidea): Distribution, biology, and fisheries. In: Paul AJ, Dawe EG, Elner R, Jamieson GS, Kruse GH, Otto RS, SainteMarie B, Shirley TC, Woodby D (eds) Crabs in cold water regions: biology, management, and economics. University of Alaska Sea Grant College Program AK-SG-02-01, Fairbanks, pp 751-845 